\title{
Early Dietary Antigens Delay the Development of Gut Mucosal Barrier in Preweaning Rats
}

\author{
TAINA ARVOLA, IMMO RANTALA, AULIS MARTTINEN, AND ERIKA ISOLAURI \\ University of Tampere, Department of Clinical Sciences, Tampere, Finland
}

\begin{abstract}
To determine the effects of early antigen exposure on the maturation of the gastrointestinal mucosal barrier, rat pups were divided into three groups at the age of $14 \mathrm{~d}$. In addition to normal maternal milk, group CM ( $n$ $=24$ ) received daily a gavage feed of cow's milk and group PH $(n=20)$ a whey protein hydrolysate during the experimental feeding period (14-20 d). Controls $(n=15)$ remained on maternal milk only. At 21 d, when "gut closure" normally occurs, intestinal absorption of horseradish peroxidase (HRP), was examined in vitro in Ussing chambers. The absorption of intact HRP Igeometric mean (95\% confidence interval) was significantly higher in group CM $\left[35.3(16.7,74.7) \mathrm{ng} \cdot \mathrm{h}^{-1} \cdot \mathrm{cm}^{-2}\right]$ than in group PH $[5.2(1.4$, 19.5) $\left.\mathrm{ng} \cdot \mathrm{h}^{-1} \cdot \mathrm{cm}^{-2}\right]$ and in controls $\left[3.4(0.8,15.1) \mathrm{ng} \cdot \mathrm{h}^{-1}\right.$. $\left.\mathrm{cm}^{-2} ; F=5.54, p=0.006\right]$. The absorption of degraded HRP was comparable in all groups. There were no modifications in electrical parameters in association with increased mucosal permeability to HRP. Furthermore, in group CM electron-microscopic studies disclosed accumulation of HRP in the cytoplasm of the epithelial cells and in the intercellular spaces where cell junctions remained unaltered. These results indicate that early administration of antigens delays the process of gut closure. They further suggest that continuously enhanced endocytosis of macromolecules is induced by an insult to the mucosa as part of the host response to these antigens, irrespective of the protection afforded by maternal milk. (Pediatr Res 32: 301-305, 1992)
\end{abstract}

\section{Abbreviations}

HRP, horseradish peroxidase

CI, confidence interval

CM, rats fed cow's milk

$\mathrm{PH}$, rats fed protein hydrolysate

The gastrointestinal mucosal barrier is constantly challenged by potentially harmful substances present within the intestinal lumen. Luminal antigens may have an important role in the pathogenesis of a number of systemic and gastrointestinal disorders such as cow's milk allergy, celiac disease, and inflammatory bowel disease, which are associated with impaired mucosal barrier function (1).

Increased intestinal permeability is a frequent finding in the young (1). In infants, it is not as yet known how long this period of increased neonatal permeability of the small intestine continues $(2,3)$. However, this occurs at a period when the immune defense mechanisms are immature (4). In susceptible young infants, dietary restrictions are recommended for protection

Received August 7, 1991; accepted April 23, 1992.

Correspondence and reprint requests: Dr. Taina Arvola, Department of Clinical Sciences, University of Tampere, P.O. Box 607, 33101 Tampere, Finland. against systemic sensitization to antigens encountered by the enteral route. Previous studies have concentrated on the role of exclusive breast-feeding in the prevention of an allergic state $(5$, $6)$. These have produced inconsistent findings (7) and failed to reduce the development of allergic symptoms $(6,8)$.

This study was undertaken to examine the influence of foreign dietary antigens on the maturation of the small-intestinal mucosal barrier during a period when intestinal permeability is transiently increased. For this purpose, we used an experimental model of intestinal permeability (9) that has increased our understanding of this process.

\section{MATERIALS AND METHODS}

Animals. Newborn male and female Wistar rat pups were studied. An experimental rat model was used, the timing and pattern of gut closure being well established in rats (10). The gut of a rat remains open to the uptake of maternal milk-derived nutritional and immunologic macromolecules until the age of $21 \mathrm{~d}$, when intestinal permeability decreases to the adult level.

The animals were reared in a conventional experimental animal laboratory with barriers. The study was approved by the Institute of Animal Care and Use at the University of Tampere.

Diet. The antigens used in this study were cow's milk powder and whey protein hydrolysate powder, both obtained from the Valio Finnish Co-operative Dairies' Association, Finland. Their compositions are presented in Table 1 . These were given to pups at a dose containing protein $1.0 \mathrm{mg} / \mathrm{g}$ body weight $/ \mathrm{d}$. The diet of all dams consisted of tap water as drinking fluid and standard food pellets (from Ewos, Södertälje, Sweden), the diet thus being completely free of cow's milk antigens.

Experimental design. The pups were reared at a density of 12 pups/dam until $14 \mathrm{~d}$ of age, under natural, maternal milk conditions. At $14 \mathrm{~d}$, the pups were divided into three feeding groups. All groups remained with the mother and were breastfed with maternal milk. In addition to this, group CM $(n=24)$ received daily a gavage feed of cow's milk and bicarbonate buffer $\left(0.9 \mathrm{M} \mathrm{NaHCO}_{3}, \mathrm{pH}=7.9\right)$ and group $\mathrm{PH}(n=20)$ was gavaged with whey protein hydrolysate and bicarbonate buffer. The controls $(n=15)$ received bicarbonate buffer only. At $21 \mathrm{~d}, 24 \mathrm{~h}$ after the last administration of cow's milk or whey protein hydrolysate, the animals were anesthetized with intraperitoneal pentobarbital $(30-40 \mathrm{mg} / \mathrm{kg}$ ) and surgically prepared for intestinal transport studies to assess the small intestinal function and morphology after the experimental feeding period.

Reagents. The reagents used in Ussing chamber studies were a 40-kD glycoprotein HRP (Sigma type VI, Sigma Chemical Co., St. Louis, MO) and ${ }^{125} \mathrm{I}$-HRP, iodinated using $500 \mu \mathrm{Ci}$ of ${ }^{125} \mathrm{I} /$ $1.0 \mathrm{mg}$ HRP according to the method of Markwell (11). HRP used in morphologic studies was type II (Sigma Chemical Co.). All reagents were dissolved in Ringer solution $(\mathrm{pH}=7.4)$ containing in mM $140 \mathrm{Na}, 5.2 \mathrm{~K}, 1.2 \mathrm{Ca}, 1.2 \mathrm{Mg}, 120 \mathrm{Cl}, 25 \mathrm{HCO}_{3}$, $2.4 \mathrm{HPO}_{4}$, and $0.4 \mathrm{H}_{2} \mathrm{PO}_{4}$.

Ussing chamber studies. The abdominal cavity was opened to remove a $10-\mathrm{cm}$ segment of jejunum beginning $10 \mathrm{~cm}$ distal to 
Table 1. Composition of cow's milk powder and whey protein hydrolysate powder used in experimental feeding of rat pups

\begin{tabular}{ccc}
\hline & $\begin{array}{c}\text { Cow's milk } \\
\text { powder }\end{array}$ & $\begin{array}{c}\text { Whey protein } \\
\text { hydrolysate } \\
\text { powder }\end{array}$ \\
\hline Protein* & 35.0 & 75.2 \\
(MW) $\dagger$ & $14000-23000 \mathrm{D}$ & $<2000 \mathrm{D}$ \\
Carbohydrate* & 52.0 & 3.2 \\
Fat* $^{*}$ & 1.0 & 0.4 \\
Ash* $_{\text {Moisture* }}$ & 8.0 & 7.1 \\
\hline
\end{tabular}

* Grams per $100 \mathrm{~g}$ powder.

$\dagger \mathrm{MW}$, molecular weight.

the ligament of Treitz. The tissue was rinsed free of intestinal contents and opened along the mesenteric border. The piece of jejunum was laid flat on a Millipore filter (HAWP $0.45 \mu \mathrm{m}$ ), mounted in Ussing chamber (exposed area $0.15 \mathrm{~cm}^{2}$ ), and bathed on both sides with $1.5 \mathrm{~mL}$ of Ringer solution. The solution was oxygenated, circulated, and maintained at $37^{\circ} \mathrm{C}$.

The solutions bathing the mucosal and serosal sides were connected via $3 \mathrm{M} \mathrm{KCl}$ agar bridges to calomel electrodes for measurement of transepithelial potential difference and to $\mathrm{Ag}$ $\mathrm{AgCl}$ electrodes for the passage of current through the system. Fluxes were measured under open-circuit conditions. Total ionic conductance was regularly assessed by passing a $10-\mu \mathrm{A}$ current through the preparation. Short-circuit current was then calculated, taking into account the fluid and filter resistance.

HRP was added to the mucosal compartment at a final concentration of $0.4 \mathrm{mg} / \mathrm{mL}$ to quantitate the absorption of the protein in its intact form. ${ }^{125}$ I-HRP was used as a tracer for the quantitation of total protein absorption. For $110 \mathrm{~min}, 800-\mu \mathrm{L}$ samples were taken from the serosal side at 20 -min intervals and replaced by fresh Ringer solution. The amount of intact protein appearing in the serosal compartment was assessed by measuring the activity of $\mathrm{HRP}$ using $\mathrm{H}_{2} \mathrm{O}_{2}$ as the substrate and $\mathrm{O}$-dianisidine as the dye. A previous Ussing chamber study has shown by gel chromatography that only intact fraction of HRP has enzymatic activity (12). Total HRP absorption was assessed by counting the radioactivity of $500-\mu \mathrm{L}$ aliquots from the samples. The absorption of degraded HRP was then calculated by subtracting the absorption of intact HRP from total protein absorption.

Morphologic studies. For morphologic examinations, a loop of jejunum was prepared as previously described (9). Briefly, approximately $10-\mathrm{cm}$ loops of jejunum distal to the ligament of Treitz were isolated in vivo, maintaining vascularization of the segment. The loops were cannulated at their proximal and distal ends, washed with Ringer solution $\left(37^{\circ} \mathrm{C}\right)$, and kept intraabdominally moist. After a $1-\mathrm{h}$ equilibration period, a $1.0-\mathrm{mL}$ aliquot of $5.0 \mathrm{mg} / \mathrm{mL}$ HRP in Ringer solution was infused into the loops for $30 \mathrm{~min}$.

Electron-microscopic cytochemistry. The intestinal mucosa was fixed in situ for 3 min by infusion of the loop with $2 \%$ glutaraldehyde buffered with $0.1 \mathrm{~mol} / \mathrm{L}$ phosphate buffer ( $\mathrm{pH}$ 7.4). The tissue was then excised and sliced into small fragments, and the fixation continued at $4^{\circ} \mathrm{C}$ for $2 \mathrm{~h}$. After overnight washing at $4^{\circ} \mathrm{C}$ in phosphate buffer containing $7.5 \%$ sucrose, the tissue samples were embedded in $6 \%$ agarose. One-hundred- $\mu \mathrm{m}$ sections were then cut with a Smith and Farquhar tissue-chopper (Sorvall TC2; Du Pont Company, New Town, CT). After washing of the sections in sucrose-phosphate buffer, HRP activity was revealed by incubation of the sections in diaminobenzidine without $\mathrm{H}_{2} \mathrm{O}_{2}$ for 15 min followed by diaminobenzidine together with $\mathrm{H}_{2} \mathrm{O}_{2}$ for an additional $30 \mathrm{~min}$ at room temperature. After washing and osmification, the sections were conventionally processed into Epon blocks. Ultrathin sections were examined without poststaining.

Cytochemical control included infusion of the intestinal loops from three rats with Ringer solution without HRP. Endogenous peroxidase activity was then demonstrated as described above.

Statistical analysis. Logarithmic transformations ( $\ln$ ) were applied because of skewed distribution in the HRP fluxes. Geometric means are presented with $95 \% \mathrm{CI}$. Analysis of variance was used to determine the statistical significance of differences in continuous variables. For comparison of several pairs of means, a series of $95 \%$ CI was constructed, using the Tukey test (13).

\section{RESULTS}

Clinical. As a result of randomization, the pups were similarly sized in the study groups at the beginning of the feeding protocol (Fig. 1). Weight gain in group CM was identical to that of controls. Animals in group PH showed a somewhat slower rate of growth. However, at the time of intestinal permeability studies, the mean (SD) weight gain were comparable in the three study groups: in group CM it was $146(11) \%$, in group PH it was 139 (3)\%, and in controls it was $144(8) \%$.

HRP Absorption in Ussing Chambers. Mucosal-to-serosal transport of HRP, measured for $110 \mathrm{~min}$ after the addition of HRP to the mucosal compartment, remained constant between 50 and $110 \mathrm{~min}$. The absorption is therefore reported as a mean of the measurements made during this steady-state period.

The absorption of intact HRP. Figure 2 compares the intact HRP absorption in rat pups receiving cow's milk powder or whey protein hydrolysate powder with that of controls. The distinction between the study groups was attributable to the high intact HRP absorption in group CM. The (In) difference between these and the controls was $2.3(95 \% \mathrm{CI} 0.7,4.0) \mathrm{ng} \cdot \mathrm{h}^{-1} \cdot \mathrm{cm}^{-2}$, whereas that between group PH and controls, $0.4(-1.4,2.3) \mathrm{ng} \cdot \mathrm{h}^{-1} \cdot \mathrm{cm}^{-2}$, was statistically not significant (Tukey test).

The absorption of degraded HRP. Altogether $97 \%$ of the total HRP absorbed was transported along the degradative pathway. The mean $(95 \% \mathrm{CI})$ absorption of degraded HRP by the jejunal epithelium was $1869(368,9500) \mathrm{ng} \cdot \mathrm{h}^{-1} \cdot \mathrm{cm}^{-2}$ in group $\mathrm{CM}$ and $3956(2816,5558) \mathrm{ng} \cdot \mathrm{h}^{-1} \cdot \mathrm{cm}^{-2}$ in group $\mathrm{PH}$. These results were not significantly different from those of the controls [2088 (282, $\left.15475) \mathrm{ng} \cdot \mathrm{h}^{-1} \cdot \mathrm{cm}^{-2} ; F=0.35, p=0.71\right]$.

Electrical Parameters. The electrical parameters, potential difference, total ionic conductance, and short-circuit current are presented as the means of the measurements carried out during the steady state period of HRP transport. As shown in Table 2, the electrical parameters remained comparable in the study groups. The conductance remained unaltered in group $\mathrm{CM}$, reflecting the integrity of the jejunal mucosa.

Electron Microscopy. The morphology of the jejunal epithelium was normal and indistinguishable between the study groups. Figure 3 depicts the electron micrograph of absorptive epithelial cells of a rat pup fed with cow's milk and shows that the adhesion of epithelial cells is intact.

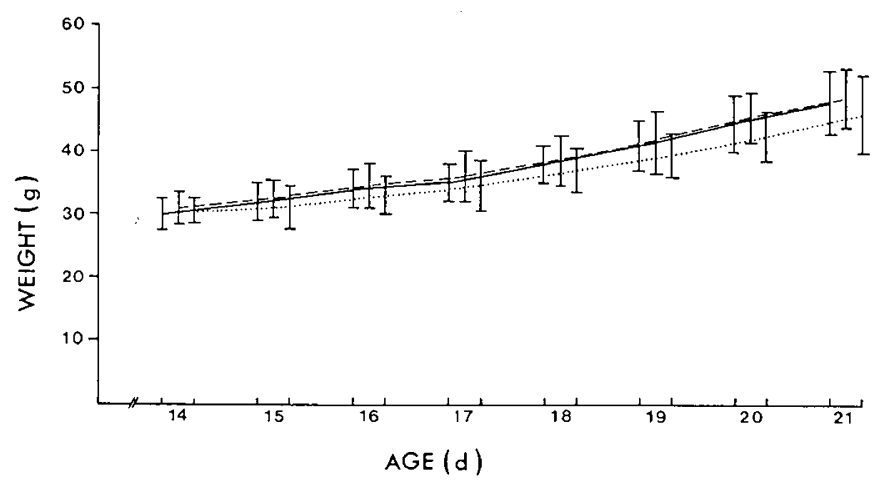

Fig. 1. Weight gain over the experimental period in controls ), in rat pups gavaged with cow's milk (-- -), and in rat pups gavaged with whey protein hydrolysate (...). Results are expressed as mean (SD). 


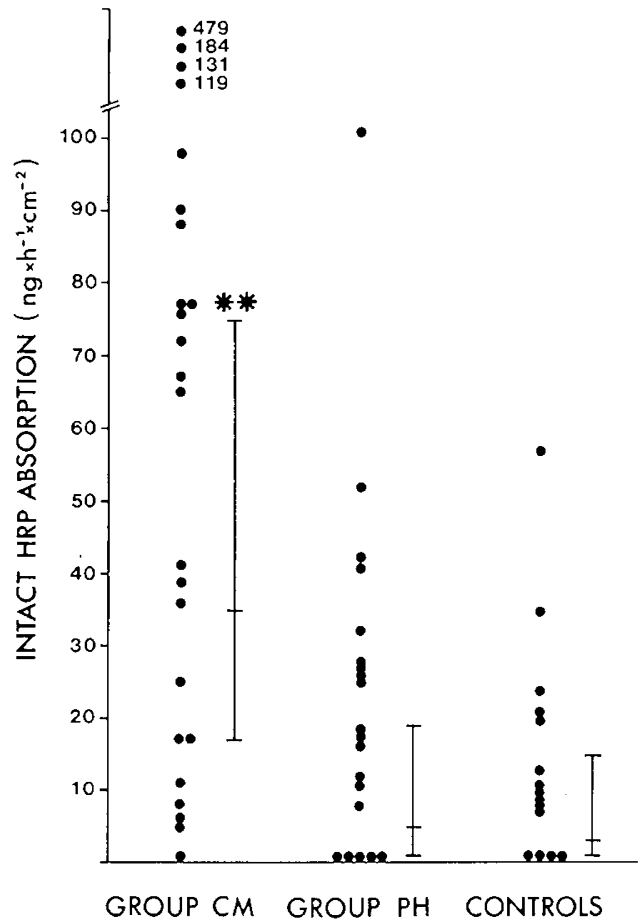

Fig. 2. The absorption of intact HRP in rat pups gavaged with cow's milk (group $\mathrm{CM}$ ), in rat pups gavaged with whey protein hydrolysate (group $\mathrm{PH}$ ), and in controls. The points represent individual animals. Horizontal bars with vertical lines denote geometric means with $95 \% \mathrm{CI}$. $F=5.54, p=0.006 .{ }^{* *}$, statistically significant difference $v s$ group $\mathrm{PH}$ and controls (Tukey test).

Table 2. Electrical parameters, potential difference (PD), total ionic conductance $(G)$, and short circuit current $\left(I_{\mathrm{SC}}\right)$ of rat jejunal tissues measured during HRP transport studies*

\begin{tabular}{ccccc}
\hline & $\begin{array}{c}\text { Group CM } \\
(n=24)\end{array}$ & $\begin{array}{c}\text { Group PH } \\
(n=20)\end{array}$ & $\begin{array}{c}\text { Controls } \\
(n=15)\end{array}$ & ANOVA $\dagger$ \\
\hline $\mathrm{PD}(\mathrm{mV})$ & 0.8 & 0.8 & 0.5 & $F=1.27$ \\
& $(0.6,1.2)$ & $(0.6,1.2)$ & $(0.2,1.2)$ & $p=0.29$ \\
$\mathrm{G}\left(\mathrm{mS} / \mathrm{cm}^{2}\right)$ & 12.0 & 10.3 & 13.4 & $F=1.27$ \\
& $(9.6,15.0)$ & $(8.7,12.2)$ & $(9.9,18.1)$ & $p=0.29$ \\
$\mathrm{I}_{\mathrm{SC}}\left(\mu \mathrm{A} / \mathrm{cm}^{2}\right)$ & 10.5 & 9.0 & 7.2 & $F=0.46$ \\
& $(7.0,15.6)$ & $(5.6,14.5)$ & $(2.9,17.8)$ & $p=0.63$ \\
\hline
\end{tabular}

* Data are the mean $(95 \% \mathrm{CI})$ steady state values.

$\dagger$ ANOVA, analysis of variance.

In group $\mathrm{CM}$, accumulation of HRP in the cytoplasm of the epithelial cells was a prominent finding (Fig. 4). Reaction product for HRP was enriched in endoplasmic reticulum, cytoplasmic vesicles morphologically resembling endosomes, and prelysosomes with tightly packed membrane figures or typical lysosomes. The vesicles were in close contact with the Golgi apparatus. In group $\mathrm{CM}$, the tracer was also detected in the intercellular spaces both apically and basally (Figs. 4 and 5). Cytochemical controls confirmed the specificity of the staining.

\section{DISCUSSION}

The results presented here indicate that early exposure to dietary antigens delays the maturation of the small-intestinal barrier. They further suggest that this may not be prevented by protective factors in maternal milk.

The intestinal permeability to macromolecules is transiently increased postnatally $(14,15)$. Gut closure, the cessation of enhanced neonatal macromolecular absorption, occurs as a result of active maturational events in gastrointestinal development (10). A major defense barrier develops against the penetration of



Fig. 3. Electron micrograph of absorptive epithelial cells from a jejunal loop of a 21-d-old rat gavaged with cow's milk. The loop was perfused with HRP for $30 \mathrm{~min}$ after a 1-h equilibration period. The tracer is present along the microvillous brush border and in some endocytotic vesicles (arrows). The cell junctions (arrowheads) between epithelial cells are intact. $\times 23000$.

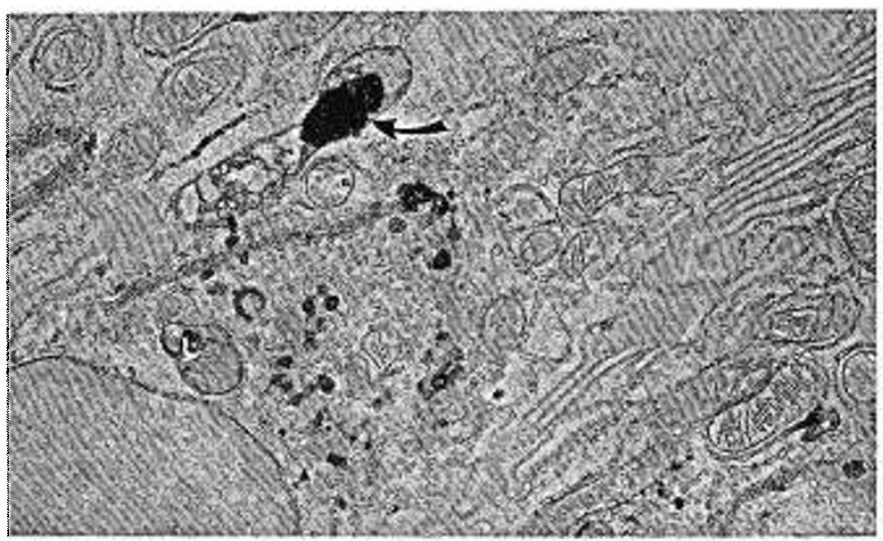

Fig. 4. Jejunal absorptive cell from a 21-d-old rat gavaged with cow's milk. Reaction product is present in an intercellular space (arrow), in endoplasmic reticulum, and in cytoplasmic vesicles. $\times 25000$,

potentially harmful substances present within the intestinal lumen. Even under physiologic conditions, however, small quantities of macromolecules are absorbed in antigenic form (16). In health, there is no evidence of inflammation in gut mucosa 

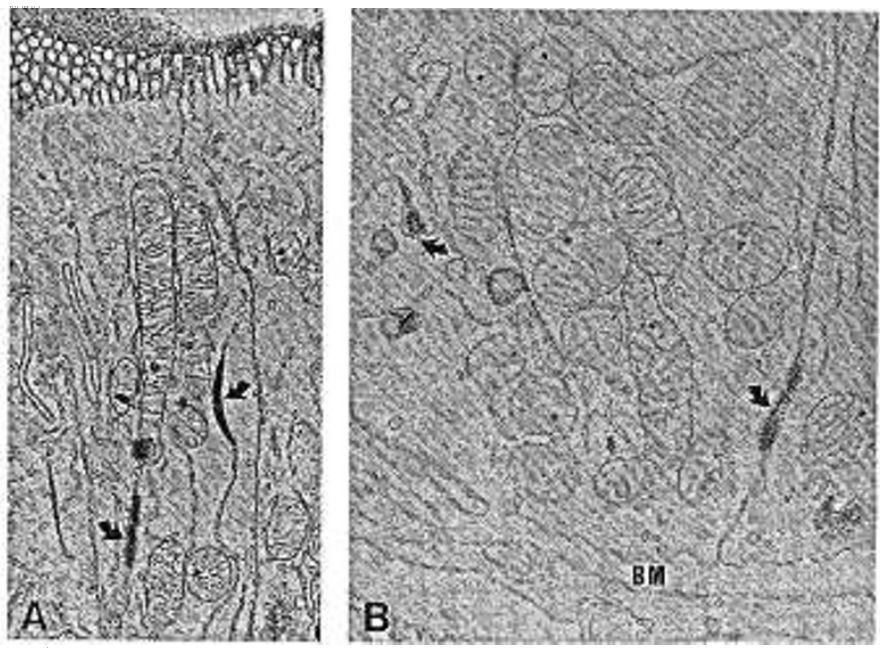

Fig. 5. Electron micrograph of the jejunal mucosa of a 21-d-old rat gavaged with cow's milk. HRP reaction product is demonstrated in intercellular spaces (arrows) both apically $(A)$ and basally $(B) . B M$, basement membrane. $A, \times 13000 . B, \times 33000$.

despite the transport of intact dietary antigens (17). Instead, antigen-specific systemic hyporesponsiveness ensues.

The rat is relatively immature at birth, compared to humans, and acquires passive immunity from maternal milk-derived Ig by receptor-mediated endocytosis (18). In the rat, the process of gut closure is well defined, beginning at the age of $14 \mathrm{~d}$ and completing at the age of $21 \mathrm{~d}(9,10)$. In humans, the precise mechanisms of intestinal maturation remain elusive. There is increasing evidence to suggest that a period of enhanced intestinal permeability and macromolecular uptake also exists in the human newborn $(14,19)$

In the Ussing chamber studies, the pups receiving daily a gavage feed of cow's milk had increased intact HRP absorption, whereas the absorption of degraded HRP remained unaltered. This confirms previous findings that intact and degraded proteins are absorbed along different routes (12). Both pathways of HRP transport are likely to be transcellular, because in the morphologic examinations the cell adhesions remained unaffected and the total ionic conductance, which is an index of paracellular pathway (2), was not elevated in the present study.

The observed increase in the absorption of intact HRP may reflect delay in the physiologic decrease of intact protein absorption that occurs with age (20). Enhanced microvillus binding of proteins and decreased protein breakdown are characteristic of immature jejunal mucosa (21). Increased endocytosis and uptake of proteins, which were also demonstrated in the present study, are additionally associated with immature enterocytes (22). We found, in group $\mathrm{CM}$, the tracer in the intercellular space of the absorptive epithelial cells as well as in the intermediate compartment of the lysosomal pathway and in close contact with the Golgi apparatus. A possible explanation of the presence of HRP in the endoplasmic reticulum concerns the development of the lysosomal system. Our findings thus give support to the postulation that a greater quantity of proteins ingested by the intestinal epithelial cells escape intracellular proteolysis as a result of immature lysosomal function (23).

The factors regulating intestinal maturation are incompletely understood. Feeding practices in early infancy may have prolonged consequences and may lead to permanent heightened immune response to dietary antigens consumed in large quantities. It was suggested in a previous experimental study that delay of gut closure upon early weaning to artificial diets could result from the lack of maternal milk factors, such as insulin, cortisol, and epidermal growth factor (24), required for normal gut closure (9). The results of the present study conflict with this suggestion by demonstrating continuously enhanced intestinal permeability in pups receiving cow's milk antigens even during breast-feeding. In contrast, we found that feeding a whey protein hydrolysate during breast-feeding did not impede normal intestinal maturation. This may be due to lower antigenic load, because by extensive hydrolyzation of cow's milk proteins during the preparation of protein hydrolysates only minimal residual peptide fractions remain.

Both human and animal studies have provided evidence that the antigen load to the offspring may be reduced by maternal specific antibodies and secretory IgA antibodies $(25,26)$. The decrease in intestinal uptake of antigen by preexisting antibodies may be highly antigen specific, because enhanced penetration of unrelated macromolecules has been demonstrated to occur simultaneously $(27,28)$. The dams in the present study did not have immune experience of the antigens investigated. Therefore, it is improbable that the maternal milk on which the pups were fed contained cow's milk antibodies.

On the basis of our results, we believe that continuously enhanced endocytosis of HRP is induced by an insult to the mucosa as part of the host immune response to cow's milk antigens. In support of this suggestion, we have recently found that the number of specific antibody-secreting cells against $\beta$ lactoglobulin is increased in the blood of rat pups receiving cow's milk through 14-20 d of age as an index of immune system activation (Arvola T, Isolauri E, Rantala I, Kaila M, Virtanen E, Arvilommi $\mathrm{H}$, unpublished manuscript). This response showed, however, interindividual variation that may explain the observed wide range of intact HRP absorption in pups gavaged with cow's milk. Direct studies in animals and indirect studies in humans suggest that morphologic and functional alterations are associated with different hypersensitivity reactions (29). The mucosal changes seen in immediate hypersensitivity reactions include edema, enterocyte shedding, and disruption of the basement membrane, whereas delayed cell-mediated reactions lead to villus atrophy and crypt hyperplasia. These may well lead to enhanced transport of macromolecules.

Although the results of the present experimental study cannot be extrapolated directly to human beings, they suggest that feeding protein antigens at a time when gastrointestinal mucosal barrier functions are immature can predispose the infant to disturbances in intestinal immunologic and nonimmunologic defense mechanisms. Young infants at high risk for allergy for whom supplementary feedings are indicated may benefit from a protein hydrolysate formula that reduces the extent of exposure. to cow's milk antigens.

Acknowledgment. The authors thank Dr. Pertti Arvola and Raija Hukkila for their excellent technical assistance.

\section{REFERENCES}

1. Lifschitz $\mathrm{CH}$, Schulman RJ 1990 Intestinal permeability tests: are they clinically useful? J Pediatr Gastroenterol Nutr 10:283-287

2. Heyman M, Grasset E, Ducroc R, Desjeux JF 1988 Antigen absorption by the jejunal epithelium of children with cow's milk allergy. Pediatr Res 24:197202

3. Roberton DM, Paganelli R, Dinwiddie R, Levinsky RJ 1982 Milk antigen absorption in the preterm and term neonate. Arch Dis Child 57:369-372

4. Strobel S 1990 Immunologically mediated damage to the intestinal mucosa. Acta Paediatr Scand 365:46-57

5. van Asperen PP, Kemp AS, Mellis CM 1984 Relationship of diet in the development of atopy in infancy. Clin Allergy 14:525-532

6. H $\phi$ st A, Husby S, $\emptyset$ sterballe O 1988 A prospective study of cow's milk allergy in exclusively breast-fed infants. Incidence, pathogenetic role of early inadvertent exposure to cow's milk formula, and characterization of bovine milk protein in human milk. Acta Paediatr Scand 77:663-670

7. Kramer MS 1988 Does breast feeding help protect against atopic disease? Biology, methodology, and a golden jubilee of controversy. J Pediatr $112: 181-190$

8. Savilahti E, Tainio VM, Salmenperä L, Siimes MA, Perheentupa J 1987 Prolonged exclusive breast feeding and heredity as determinants in infantile atopy. Arch Dis Child 62:269-273

9. Teichberg S, Isolauri E, Wapnir RA, Roberts B, Lifshitz F 1990 Development of the neonatal rat small intestinal barrier to nonspecific macromolecular absorption: effect of early weaning to artificial diets. Pediatr Res 28:31-37 
10. Henning SJ 1987 Functional development of gastrointestinal tract. In: Johnson LR (ed) Physiology of the Gastrointestinal Tract. Raven, New York, pp 285 300

11. Markwell M 1982 A new solid-state reagent to iodinate proteins. I. Conditions for the efficient labeling of antiserum. Anal Biochem 125:427-432

12. Heyman M, Ducroc R, Desjeux JF, Morgat JL 1982 Horseradish peroxidase transport across adult rabbit jejunum in vitro. Am J Physiol 242:G558-G564

13. Winer BJ (ed) 1971 Statistical principles in experimental design. McGraw-Hill Tokyo, pp 201-204

14. Beach RC, Menzies IS, Clayden GS, Scopes JW 1982 Gastrointestinal permeability changes in the preterm neonate. Arch Dis Child 57:141-145

15. Udall JN, Pang K, Fritze L, Kleinman R, Walker WA 1981 Development of gastrointestinal mucosal barrier. I. The effect of age on intestinal permeability to macromolecules. Pediatr Res 15:241-244

16. Husby S, Jensenius JC, Svehag SE 1986 Passage of undegraded dietary antigen into the blood of healthy adults. Further characterization of the kinetics of uptake and the size distribution of the antigen. Scand J Immunol 24:447455

17. Brandtzaeg P, Halstensen TS, Kett K, Krajci P, Kvale D, Rognum TO, Scott H, Sollid LM 1989 Immunobiology and immunopathology of human gut mucosa: humoral immunity and intraepithelial lymphocytes. Gastroenterology 97:1562-1584

18. Abrahamson DR, Powers A, Rodewald R 1979 Intestinal absorption of immune complexes by neonatal rats: a route of antigen transfer from mother to young. Science 206:567-569

19. Axelsson I, Jakobsson I, Lindberg T, Polberger S, Benediktsson B, Räihä N 1989 Macromolecular absorption in preterm and term infants. Acta Paediatr
Scand 78:532-537

20. Isolauri E, Gotteland M, Heyman M, Pochart P, Desjeux JF 1990 Antigen absorption in rabbit bacterial diarrhea (RDEC-I). In vitro modifications in ileum and Peyer's patches. Dig Dis Sci 35:360-366

21. Stern M, Pang KY, Walker WA 1984 Food proteins and gut mucosal barrier. II. Differential interaction of cow's milk proteins with the mucous coat and the surface membrane of adult and immature rat jejunum. Pediatr Res 18:1252-1257

22. Heyman M, Crain-Denoyelle AM, Desjeux JF 1989 Endocytosis and processing of protein by isolated villus and crypt cells of the mouse small intestine. J Pediatr Gastroenterol Nutr 9:238-245

23. Walker WA 1982 Mechanisms of antigen handling by the gut. Clin Immunol Allergy 2:15-40

24. Sheard NF, Walker WA 1988 The role of breast milk in the development of the gastrointestinal tract. Nutr Rev 46:1-8

25. Harmatz PR, Bloch KJ, Kleinman RE, Walsh MK, Walker WA 1986 Influence of circulating maternal antibody on the transfer of dietary antigen to neonatal mice via milk. Immunology 57:43-48

26. Kleinman RE, Walker WA 1979 The enteromammary immune system. An important new concept in breast milk host defense. Dig Dis Sci 24:876-882

27. Brandtzaeg P, Tolo K 1977 Mucosal penetrability enhanced by serum-derived antibodies. Nature 266:262-263

28. Lim PL, Rowley D 1982 The effect of antibody on the intestinal absorption of macromolecules and on intestinal permeability in adult mice. Int Arch Allergy Appl Immunol 68:4 I-46

29. Patrick MK, Gall DG 1988 Protein intolerance and immunocyte and enterocyte interaction. Pediatr Clin North Am 35:17-34 